\title{
Research on the Optimization of Teaching Model in Local Colleges under the Background of "Internet+" -Take the hotel management as an example
}

\author{
WenJie Wang \\ Institute of Tourism and Resources Environment, College of Zaozhuang, Shandong, China
}

Keywords: Internet +, teaching model, hotel management.

\begin{abstract}
This paper analyzes the influence of "Internet + " on the traditional teaching model of local colleges, and combines the different manifestations of the innovative teaching model of local colleges in the era of "Internet + ", and discusses and explores the optimization of the teaching model of hotel management in the local college in the era of "Internet +", It is pointed out that the hotel management should further be improved the digital teaching platform under the background of the new era, and integrated into the new teaching methods, optimized the professional curriculum system and network, ladder, systematic teaching system innovation and so on, so as to further promote the cultivation of innovative talents of high quality of hotel management.
\end{abstract}

Introduction

\section{Introduction}

"Internet + " is the use of Internet platform and information communication technology to make the Internet and traditional industries deeply integrated and to create new ecological development[1] .Since Premier Keqiang Li put forward "Internet +" program, all walks of life set off a "Internet +" boom. As one of the important bases for the training of talents in all walks of life,the teaching model and development of college is bound to be influenced by the times of "Internet +".

\section{The Influence of "Internet +" on the Traditional Teaching Mode of Local College}

\section{Learning to open, students demand for information and learning way have been changed due to the Internet.}

In the case of massive information resources on the Internet, the global shared knowledge base is accelerating, and many knowledge points are open to explain, many questions are raised and answered,They are interested in knowledge, resources and help through the Internet at any time and anywhere, learning is no longer limited to books and classrooms.

The educational function of teachers is weakened.

Under the traditional educational model, the rich thinking, professional knowledge and charisma of an excellent teacher will have a great impact on students. The students' knowledge sources depend mainly on the teaching of teachers and the reading of books and materials. Teacher's personality charm and professional knowledge have a great help to the formation of students' good quality. But on the Internet, especially mobile Internet under the teacher's authority and influence weakened, knowledge about network teachers can be found on the relevant information, better some online resources than the teacher, the teacher's authority and educational function is weakened.

Education has become wisdom, college teacher's teaching way then needs to change.

With the rapid development and innovation of Internet and mobile electronic devices, big data, MOOC, wisdom technology and virtual assistant technology and so on, Education can show a "wisdom" in accordance with their aptitude and convenient and efficient features. College teachers should also follow the trend of the times, actively learn and use new teaching tools and method in 
order to more fully and efficiently present and solve the problem that students interested in the field, knowledge points and solution to various professional issues.

\section{The Innovation of Local College ’Teaching Model in Times of "Internet +"}

\section{Micro-lectures, flipped classroom, cloud classroom and other new teaching methods begin to apply.}

The micro-lectures is an emerging modern teaching method under the background of Internet + education. Its construction cost is low, which can realize the construction and sharing of heavy and difficult teaching resources by integrating various technologies such as audio and video. Students can not only look through the graphic audio and video knowledge online, but also study anytime after downloading. The difference of the classroom teaching model in between flipped classroom is that the class can be released through the teacher's video and other resources to complete the knowledge point of learning, but the classroom dominated by traditional explanations of the teacher has become a place for students to discuss and exchange knowledge with certain teachers[2], Classroom and teacher's role under the flipped classroom teaching mode has changed, the teacher's more responsibility is to understand the students' problems and guide them to better learn and use the knowledge learned[3]. "Cloud Classroom" is a kind of teaching classroom based on cloud computing technology, teachers only need to use the Internet, use easily interface operation, you can quickly and efficiently synchronize with students to share voice, video and data files, and arrange for different learning tasks and practice methods according to students characterized by difference. The application of the new teaching method fully respects the student's main position in learning, and greatly activates the student's enthusiasm and participation. The integration of new teaching methods also further facilitates students' understanding of learning and mastery of knowledge.

The whole process information management of theory teaching system and practice teaching system.

The rapid development of Internet technology makes it possible for universities to develop a mobile terminal based teaching management system through the development of mobile APP technology. Mobile APP provide the use of teaching resources in the teaching system, students from attendance to the class situation, teaching tasks and submission and student evaluation and other functions, optimizing teaching management mode, theory and practice of teaching resources, improve the openness of theoretical and practical teaching resources and student learning convenience, so as to improve the quality of teaching management.

\section{The innovation of the curriculum system: increase of new informationization application} courses and reduction of public theoretical courses.

In the "Internet +" era, the industry needs to increase public information talent and many public theory courses can be used to share online quality resources to learn the way to complete, in order to adapt to the change environment and development requirements, local universities proceed the corresponding adjustment of the curriculum system and personnel training. According to the characteristics of students and different majors, it is closely related to the talent demand of the industry and fully takes into account the characteristics of the Internet talent in the Internet age[4],In the design of curriculum system ,we will gradually be through online learning "theory" to the line, In order to strengthen the ability of teaching contents and curriculum system as the core, the practical application of the characteristics of the teaching content and curriculum system.

\section{The continuous optimization of teacher education concept and ability.}

Under the Internet age, the global teaching resources and knowledge sharing, as awe should change the education idea, strengthen learning, update knowledge and skills, improve their ability and quality to adapt to the needs of the information society. In the new teaching environment, Teachers' role gradually transformed into guider for student learning, collaborators, motivators, mentors and so on. Teachers should think about how to help students change "data" into "information", and transform "knowledge" into "application ability". Therefore, teachers need to master new educational technology, and fully study the various elements and links of teaching, so as to better adapt to the new educational needs and achieve better teaching results. 
The continuous optimization of teaching feedback and evaluation system.

The change of new teaching mode makes it possible for students to feedback and evaluate the teaching process and the learning of knowledge points, so that it is more conducive to the implementation of teaching students in accordance with their aptitude. The scientific and fair evaluation system is an important link and method to promote and test effective study and teaching "Internet +"era make teaching methods change at the same time, the assessment and evaluation system can also carry out timely assessment and evaluation through a comprehensive Internet teaching platform.

\section{Thoughts on the Optimization of Teaching Model of Hotel Management in Local College in the Age of the Internet + .}

To build a sound system of digital teaching platform, and further optimize the teaching system of hotel management.

It is open and easy to use digital teaching platform, which can provide hotel management major teaching with the convenient platform and system, and will play a better role in promoting and promoting for the hotel management major teaching. The arrival of the mobile Internet era make college students easily carry out a variety of information query and learning by using their phone. But at present, most of school teaching platform function of the hotel management major is still not perfect, teachers and students can not fully and easily communicate the professional knowledge by using the network platform, and various teaching resources and practical resources have not been able to better integrate into the convenient digital platform. This requires are following as below.at first, we build the comprehensive teaching application platform, and then let the teaching system, teaching resources system, learning system, discussion and feedback system, evaluation system and etc. integrate into the system, and unify system planning and management.

Network, ladder and systematic teaching system innovation of hotel management.

In the establishment or reference of schools, internships and students sharing the digital teaching system platform, on the one hand, it can achieve teaching resources and practical resources of the network to share and manage, on the other hand, The teachers can upload hierarchically teaching resources in accordance with the different training modules into the teaching platform according to the different grades of students and the degree of acceptance, the internship unit can also upload hierarchically industry trends, hotel work flow and student practice tasks arrangement into the system platform, students can interact and communicate with internship units, teachers and other students in system Platform at any time, so we achieve more resources, more effective sharing, students further improve their professional knowledge and quality in the timely interaction and learning.

The further optimization of teaching subject.

In the Internet + challenge, the hotel management professional teacher subject must also be further optimized, so as to improve the overall quality of teaching and ability. Specifically, first of all, teachers must actively improve their own information literacy, actively learn new teaching methods, and actively explore a variety of the related professional knowledge and industry information, and let the new teaching technology and the concept to apply in classroom teaching, thus continue to promote their own professional knowledge, ability and teaching level. Second, the hotel management is a very practical application major, which requires that teachers not only have a wealth of theoretical knowledge, but also have the appropriate industry practice and knowledge. For the hotel management, In the current hotel expatriate teachers exercise and the introduction of the hotel distinguished experts participated in the teaching of the foundation, also can make full use of convenient communication in the network era, set up a set of professional cooperation feasible mechanism between teachers inside and outside the school, strengthen exchanges and cooperation between teachers and school personnel for the hotel industry, update the knowledge the development of the industry dynamics, and hired a hotel manager and other related staff at the end of the semester, make teaching skill evaluation according to the working standard requirements, form quality control mechanism of professional skill teaching[5].In addition, the main body of teachers should take full account of the characteristics and personality characteristics of the teaching object in the information age, guide students to learn 
actively by the teaching design and other aspects, and keep students' needs and questions by the interactive application of information platform, And give targeted counseling and Q \& A, achieve good interaction between teachers and students.

\section{Further optimization of the curriculum system}

Education is being carried out to the Internet 4.0 era[6],although it has not yet achieved full university education teaching system of the Internet, it is possible to use of internet resources for teaching system and conform to the requirements of the Internet age, which is the era of the trend, also adapt to the development of talents under the background of the new era.

With the development of hotel industry in our country, more and more hotels use information technology to improve their management ability and communication ability. Although the hotel industry is still a service-oriented industry, today's hotel service is to strive from the guests standard, provide guests with a full range of personalized and personalized service by the use of information systems. Therefore, in the hotel management curriculum, we should know the needs of university personnel training in the hotel industry, timely dock the job requirements of the hotel, strengthen the information and practice, set up innovative curriculum ,comply with demand for professionals under the background of "Internet +" in hotel industry.

\section{Conclusion}

Under the background of the "Internet +" age, the local university hotel management professional should promptly conform to the requirements of the information age, timely adjust and optimize the teaching mode, in order to more effectively promote the students' comprehensive quality of hotel management professional development and improve the quality of employment.

\section{References}

[1] Tang Li, Under the Background of "the Internet +"age, Female College Students Enhance the Ability of the Innovation. Management Manager, 2016 (12).

[2] Y. F.Wang, Research on Information Technology Literacy of the Teachers under the Concept of "Internet +".Proceedings of 2015 4th International Conference on Physical Education and Society Management(ICPESM 2015 V48).

[3] S.F.Chen,X.Li, Research and Exploration of Film Optics Course. Science and Technology Perspective, 2016 (04).

[4] X.C.Yang, The New Changes in the Teaching of the Times of Internet + . Journal of Leshan Teachers College, 2016 (04).

[5] W.Guo,S.B. Xiao and B.B.Cao, "Face to Face between Internet Education and College " seminar held in Capital Normal University. World Education Information, 2015 (15).

[6] Z.B.Peng, Study on the Teaching ModeL of "Professional Interactive Public Management under the Background of Internet +. Journal of Sichuan Vocational and Technical College, 2016 (03). 